\title{
Influence of biologically active compounds on milk production and metabolism of lactating cows
}

\author{
Roini Sharvadze ${ }^{1, *}$, Elena Gaidukova $^{1}$, Tamara Krasnoshchekova ${ }^{1}$, Ketevan Babukhadiya ${ }^{1}$, \\ and Andrey Burmaga ${ }^{1}$ \\ ${ }^{1}$ Far Eastern State Agrarian University, Blagoveshchensk, Amur Region, Russia
}

\begin{abstract}
Dairy farming is a strategic and most efficient branch of agriculture. Milk production depends on a number of factors. The practical experience of many scientists has shown that an increase in the milk productivity of cows is possible when the rations are fed in the form of complete feed mixtures (mono feed). Despite the fact that such a feeding technology contributes to an increase in milk productivity of cows, there are problems in the new calving period, related to their health. After calving, during the milking period, the cows lose their live weight, they quickly acquire metabolic disorders (liver steatosis, ketosis, acidosis, etc.). To prevent such pathological processes, it is necessary to feed energycompensating supplements in the new calving period. One of the solutions of this problems is the inclusion of biologically active compounds in feed mixtures. In our research these are feed additives "Ecostimul-2" and "Active Mix". In the process of experimental studies, the effect of feed additives "Ecostimul-2" and "Active Mix" during their separate and joint feeding to lactating cows in the new calving period on their milk productivity and metabolism was studied. As a result of the experimental studies, it was found that feeding the used additives to cows in the new calving period promotes an increase in milk yield and a faster recovery of reproductive functions.
\end{abstract}

\section{Introduction}

At present, one of the main tasks of the agro-industrial complex is to meet the needs of the population in food products of the required assortment, high quality and at affordable prices. The solution to this problem is impossible without increasing the productivity of farm animals and can be carried out only with the organization of their full feeding. Over the past few decades, the development of various branches of animal husbandry is closely related to the development and implementation of scientifically grounded animals' feeding rations, balanced in vitamin and mineral composition, using biologically active substances of various origins and purposes. Hundreds of experiments are carried out annually to develop and introduce various feed additives, most of which give a positive effect in

\footnotetext{
*Corresponding author: fvmz@dalgau.ru
} 
specific production and economic conditions. Natural, climatic and economic conditions in each region of the country affect the timing of growth and the nutritional value of forage crops [1-6]. So, within the limits of even one Amur region, indicators of feed nutritional value vary, firstly, by year, and secondly, depending on biogeochemical conditions. This excludes the possibility of using many of the recommended balancing feed additives developed for other climatic and economic conditions [2, 3, 7]. It should also be added that the companies producing various balancing additives are directly interested in selling their products. Based on the foregoing, given the lack of knowledge of these issues and the request of practice, the main task for specialists remains to understand these issues and correctly navigate which feed additives to use in their specific farms in order to balance feed rations. The solution to this problem in modern conditions is relevant, and it can directly affect the economic performance of production.

To increase milk production, various feed additives are used, in our case - Ecostimul-2 and Active Mix. Dihydroquercetin, which is a part of the feed additive Ecostimul-2, clearly manifests its antioxidant, hepato- and capillary-protective, immunomodulating, radioprotective properties [7-10]. Propylene glycol, which is part of the Active Mix feed additive, determines the efficiency of energy metabolism in a cow and has a decisive influence on the quantitative and qualitative parameters of milk protein. Propylene glycol in the Active Mix improves the provision of high-yielding cows with energy and thereby reduces the incidence of ketosis [11-14].

The aim of the research was to study the effect of Ecostimul-2 and Active Mix feed additives when fed separately and together in the diet of freshly calved cows on milk productivity, metabolism and reproductive indices.

\section{Materials and methods}

Scientific, economic and physiological experiments were carried out during 2018 in the dairy complex of Pogranichnoye LLC, typical for the conditions of the Amur Region. Experimental studies were carried out on cows of black-spotted breed with breeders of the Holstein breed. Scientific, economic and physiological (balance) experiments were carried out in accordance with the general scheme of scientific research (Fig. 1).

To carry out the scientific and economic experiment, we have chosen the method of analog groups. Animals were selected according to live weight, calving date, age, lactation period, milk productivity for the previous lactation. The preparatory period lasted up to 15 days. The accounting period of 100 days began on the second day after the transfer of cows to the main milk production facility. As a background ration, the basic ration adopted on the farm for cows during the milking period was used. In the experimental groups, the studied feed additives were introduced into the main diet. To determine milk productivity and milk quality, control milking was carried out every ten days. As part of the scientific and economic experiment, a physiological one was carried out, in which the digestibility of nutrients, the balance of nitrogen, calcium and phosphorus were determined. The analysis of feed, eaten residues, urine and feces was carried out in specialized laboratories of the Far Eastern State Agrarian University, in the central regional veterinary laboratory of the Amur region and in the laboratory of Far Eastern Zonal Research Institute of Veterinary Medicine. To study the effect of feed additives on the health and physiological state of animals, a biochemical blood test was performed. Blood was taken from the jugular vein. The hemoglobin content in the blood was determined with a Sali hemometer, the number of erythrocytes and leukocytes was determined by counting in the Goryaev chamber. Serum total protein was determined using an IRF-22 refractometer, reserve blood alkalinity according to Nevodov, phosphorus - by calorimetric method, calcium according to De Ward. To assess the reproductive qualities of the experimental cows, the day of the onset of 
estruation and the date of insemination of the cows were recorded. After 2 months, ultrasound diagnostics was performed in order to establish pregnancy. The number of pregnant cows was established, the duration of the service period was determined. The economic analysis of the results of scientific and economic experience was carried out at prevailing prices in the livestock industry of the Amur Region at the time of the experimental research. Biometric processing of research results was carried out with a special computer program "Microsoft Excel" 2013. The significance of differences was determined using the Student's statistical test.

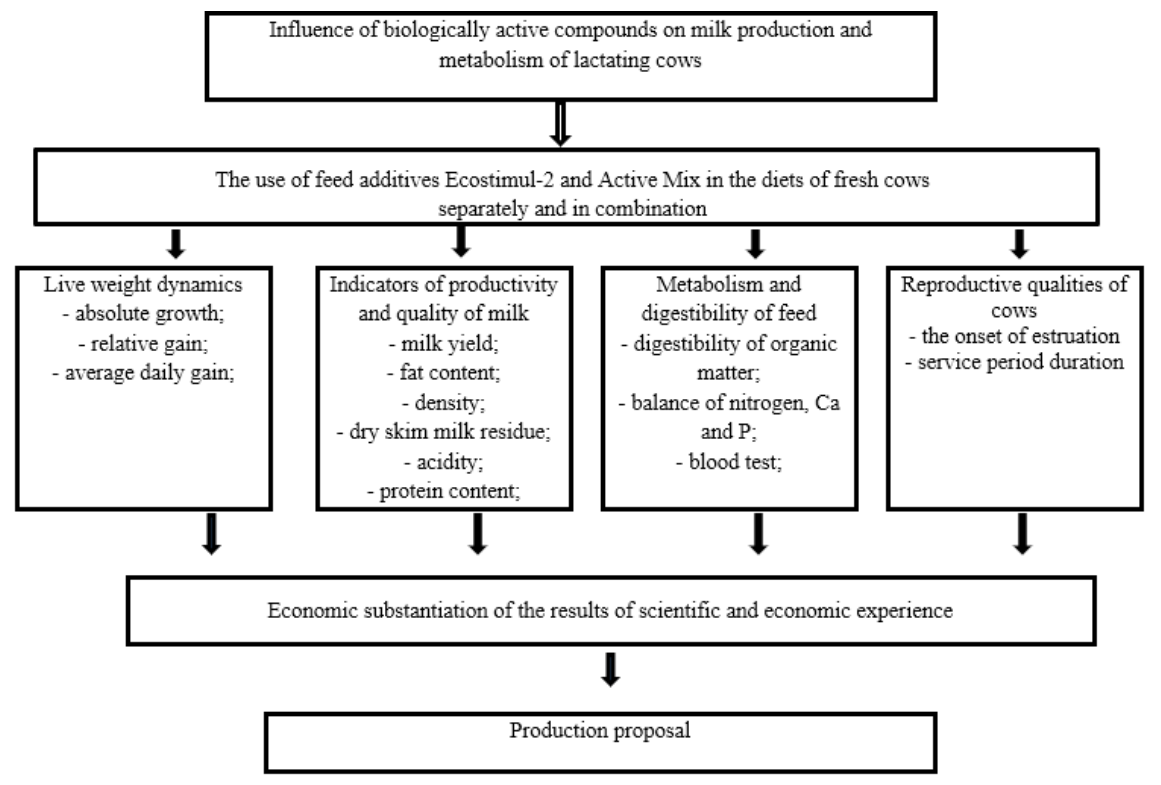

Fig. 1. General scheme of scientific research.

The duration of the scientific and economic experience was 100 days, from September 4. 2018 to December 13. 2018.

After the transfer from the maternity ward, all the cows were placed in the milk production workshop, in one barn. 4 groups were formed, one control and three experimental, 8 heads per each group (Table 1).

During the scientific and economic experiment at the dairy complex, feed rations were fed to cattle in the form of complete feed mixtures (mono feed), with their mechanized distribution.

Table 1. Scheme of scientific and economic experience.

\begin{tabular}{|c|c|c|c|}
\hline Group & $\begin{array}{c}\text { Preliminary } \\
\text { period } 7 \ldots 10 \\
\text { days. }\end{array}$ & Accounting period 100 days. & $\begin{array}{c}\text { Final period } 5 \\
\ldots \text { 10 days. }\end{array}$ \\
\hline Control & Basic diet & Basic diet & Basic diet \\
\hline I experimental & Basic diet & $\begin{array}{c}\text { Basic diet }+300 \mathrm{~g} \text { Active Mix per head per } \\
\text { day }\end{array}$ & Basic diet \\
\hline $\begin{array}{c}\text { II } \\
\text { experimental }\end{array}$ & Basic diet & $\begin{array}{c}\text { Basic diet }+300 \mathrm{~g} \text { Active Mix }+300 \mathrm{mg} \\
\text { Ecostimul-2 per head per day }\end{array}$ & Basic diet \\
\hline $\begin{array}{c}\text { III } \\
\text { experimental }\end{array}$ & Basic diet & $\begin{array}{c}\text { Basic diet }+300 \text { mg Ecostimul-2 per head } \\
\text { per day }\end{array}$ & Basic diet \\
\hline
\end{tabular}


The cows from the control group were fed the diet accepted on the farm. Cows from the first experimental group received Active Mix in addition to the main diet, cows from the second experimental group received Active Mix in the main diet together with Ecostimul-2, and cows from the third experimental group - separately Ecostimul-2. Experimental additives were distributed manually to each cow in the feeder: Active Mix was introduced in the form of a powder into each feeder, and Ecostimul-2 was in the form of colored capsules.

\section{Results}

One of the criteria for assessing the balance and usefulness of feeding cows over the period of the experiment, as well as the productive effect of a particular additive, is the dynamics of the live weight of the animal. At the beginning, middle and end of the scientific and economic experiment ( $2 \mathrm{nd}, 50$ th and 99 th day), the cows were weighed (Table 2). The live weight of cows at the beginning of the experiment did not differ between groups. After 48 days, the live weight of cows in all groups decreased by an average of $50 \mathrm{~kg}(\approx 9 \%)$. The overall decrease in live weight is due to the fact that freshly calved cows consume internal energy reserves. In the second half of the experiment, by the end of the first phase of lactation, the cows began to regain weight. This process was more intensive in the third experimental group. When cows from the third experimental group were fed with the feed additive Ecostimul-2, there was a minimum decrease in live weight by $29 \mathrm{~kg}$, versus $37 \mathrm{~kg}$ in the control group, $35 \mathrm{~kg}$ in the first experimental group and $49 \mathrm{~kg}$ in the second experimental group.

Table 2. Dynamics of live weight of cows during the experiment.

\begin{tabular}{|l|c|c|c|c|}
\hline \multirow{2}{*}{ Index } & \multicolumn{4}{|c|}{ Group } \\
\cline { 2 - 5 } & control & 1 experimental & 2 experimental & 3 experimental \\
\hline $\begin{array}{l}\text { Live weight at the } \\
\text { beginning of the } \\
\text { experiment, kg }\end{array}$ & $568.1 \pm 46.5$ & $559.4 \pm 51.2$ & $569.8 \pm 53.4$ & $549.1 \pm 41.6$ \\
\hline $\begin{array}{l}\text { Live weight in the middle } \\
\text { of the experiment, } \mathrm{kg}\end{array}$ & $522.0 \pm 52.3$ & $510 . .2 \pm 44.7$ & $524.0 \pm 50.6$ & $499.2 \pm 47.2$ \\
\hline $\begin{array}{l}\text { Absolute gain (loss) of live } \\
\text { weight for the first part of } \\
\text { the experiment, } \mathrm{kg}\end{array}$ & -46.1 & -49.2 & -45.8 & -49.9 \\
\hline $\begin{array}{l}\text { Relative gain (loss) of live } \\
\text { weight for the first part of } \\
\text { the experiment, } \%\end{array}$ & -8.1 & -8.8 & -8.0 & -9.1 \\
\hline $\begin{array}{l}\text { Live weight at the end of } \\
\text { the experiment, } \mathrm{kg}\end{array}$ & $531.1 \pm 54.1$ & $524.4 \pm 4703$ & $526.8 \pm 49.0$ & $520.1 \pm 510.6$ \\
\hline $\begin{array}{l}\text { Absolute gain (loss) of live } \\
\text { weight for the second part } \\
\text { of the experiment, kg }\end{array}$ & 9.1 & 14.2 & 2.8 & 20.9 \\
\hline $\begin{array}{l}\text { Relative gain (loss) of live } \\
\text { weight for the second part } \\
\text { of the experiment,\% }\end{array}$ & 1.7 & 2.8 & 0.5 & 4.2 \\
\hline $\begin{array}{l}\text { Absolute gain (loss) of live } \\
\text { weight per experiment, } \mathrm{gg}\end{array}$ & -37 & -35 & -49 & -29 \\
\hline $\begin{array}{l}\text { Relative gain (loss) of live } \\
\text { weight for experience, } \%\end{array}$ & -6.5 & -6.3 & -8.6 & -5.3 \\
\hline
\end{tabular}

Analysis of absolute and relative gains over the periods of experience and in general over the experience more accurately and convincingly shows the superiority of the third 
experimental group over the rest. Based on the materials of Table 2, changes in average daily gains were calculated and presented in the form of a diagram for the periods of experience and for the whole experience (Fig. 2).

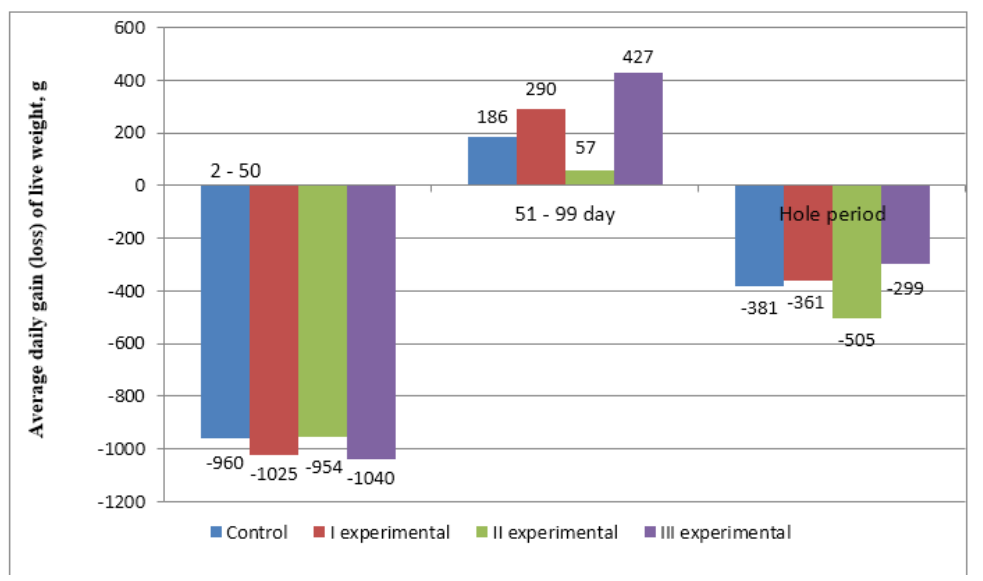

Fig. 2. Dynamics of average daily gains (weight loss) over the period of the experiment.

The diagram shows that during the first half of the experiment (from 2 to 50 days) there is an intense loss of live weight. In the second half of the experiment (from 51 to 99 days), the situation changed. The cows begin the process of restoring body weight. In general, for 100 days of lactation, cows have a negative dynamics of change in live weight, but the minimum loss is observed in cows from the third experimental group in the ration of which the feed additive "Ecostimul-2" was contained. Upon visual observation, there were no emaciated cows in the experimental groups, but cows from the second experimental group were closer to this state. From the analysis of the dynamics of live weight, it can be seen that the combined inclusion of feed additives negatively affected the studied parameters. At the same time, the separate inclusion of a feed additive in the diet of cows had a positive effect in the first experimental group when feeding "Active Mix" and in the third "Ecostimul-2". This confirms the existence of antagonistic interactions between these additives.

The main indicator of the effect of the feed ration for dairy cows is the amount of received milk and its quality.

The first control milking was carried out on the tenth day after calving. From the materials it can be seen that the productivity of cows at the beginning of the experiment did not differ significantly between groups. Thus, the average milk yield per day in cows from the control group was $22.6 \mathrm{~kg}$, in the I, II and III experimental groups - 22.7, 22.8 and 22.3 $\mathrm{kg}$ of milk, respectively (Table 3 ).

During the first decade, cows from all groups increased productivity. The best results were in cows from the first group. The average milk yield per cow was $29.1 \mathrm{~kg}$ of milk per day. The cows from the control group showed the second result $-28.3 \mathrm{~kg}$ of milk per day, but in the next decade in this group the productivity decreased to $22.7 \mathrm{~kg}$ and later remained at about the same level until the end of the 6th decade. And then again there was a sharp decline from 22.3 to $17.6 \mathrm{~kg}$ ( 7 th decade). Further, until the end of the experiment, the level of productivity did not change significantly. After the first decade, milk yield began to fall in other groups, but in the control group it happened more sharply. The highest milk yields were obtained from cows from the third experimental group, which included the feed additive Ecostimul-2 (Table 3). 
Table 3. Results of control milking by groups of cows.

\begin{tabular}{|c|c|c|c|c|c|}
\hline \multirow[b]{2}{*}{ Group } & \multirow[b]{2}{*}{$\begin{array}{l}\text { Average milk } \\
\text { yield, days, } \mathrm{kg}\end{array}$} & \multicolumn{4}{|c|}{ Milk quality indicators } \\
\hline & & $\begin{array}{l}\text { Average fat } \\
\text { content, } \%\end{array}$ & $\begin{array}{l}\text { Average protein } \\
\text { content } \% \%\end{array}$ & $\begin{array}{l}\text { Density kg / } \\
\text { m3 }\end{array}$ & $\begin{array}{l}\text { Dry skim milk } \\
\text { residue, } \%\end{array}$ \\
\hline 1 & 2 & 3 & 4 & 5 & 6 \\
\hline \multicolumn{6}{|c|}{ (1st control milking) 03.09.2018 } \\
\hline control & $22.6 \pm 2.51$ & $3.05 \pm 1.10$ & $3.16 \pm 0.04$ & $1029 \pm 1,05$ & $8.38 \pm 0.41$ \\
\hline 1 experimental & $22.7 \pm 3.38$ & $3.64 \pm 1.13$ & $3.07 \pm 0.04$ & $1028 \pm 1,11$ & $8.19 \pm 0.38$ \\
\hline 2 experimental & $22.8 \pm 2.95$ & $3.24 \pm 0.09$ & $3.04 \pm 0.05$ & $1028 \pm 1,09$ & $8.39 \pm 0.33$ \\
\hline 3 experimental & $22.3 \pm 3.41$ & $2.96 \pm 1.10$ & $3.22 \pm 0.04$ & $1029 \pm 1,10$ & $8.5 \pm 0.40$ \\
\hline \multicolumn{6}{|c|}{ 1st decade (2nd control milking) 09/14/2018 } \\
\hline control & $28.3 \pm 4.22$ & $3.35 \pm 1.01$ & $3.02 \pm 0.02$ & $1027.7 \pm 1.03$ & $8.11 \pm 0.11$ \\
\hline 1 experimental & $29.1 \pm 4.08$ & $3.23 \pm 1.12$ & $3.04 \pm 0.03$ & $1028.1 \pm 0.89$ & $8.18 \pm 0.09$ \\
\hline 2 experimental & $26.6 \pm 3.75$ & $2.71 \pm 1.03$ & $3.03 \pm 0.02$ & $1028.6 \pm 0.95$ & $8.19 \pm 0.14$ \\
\hline 3 experimental & $27.9 \pm 4.10$ & $3.68 \pm 0.98$ & $3.07 \pm 0.04$ & $1027.9 \pm 0.99$ & $8.25 \pm 0.10$ \\
\hline \multicolumn{6}{|c|}{ 2nd decade (3rd control milking) 09/24/2018 } \\
\hline control & $22.7 \pm 3.41$ & $2.89 \pm 0.72$ & $2.97 \pm 0.03$ & $1027.8 \pm 1.04$ & $8.05 \pm 0.12$ \\
\hline 1 experimental & $27.4 \pm 4.19$ & $3.0 \pm 1.04$ & $3.08 \pm 0.02$ & $1028.7 \pm 0.95$ & $8.27 \pm 0.16$ \\
\hline 2 experimental & $24.8 \pm 4.02$ & $2.97 \pm 0.86$ & $3.03 \pm 0.04$ & $1028.2 \pm 0.89$ & $8.14 \pm 0.20$ \\
\hline 3 experimental & $27.9 \pm 3.84$ & $3.27 \pm 0.91$ & $3.02 \pm 0.03$ & $1028.2 \pm 1.01$ & $8.19 \pm 0.17$ \\
\hline \multicolumn{6}{|c|}{ 3rd decade (4th control milking) 04.10.2018 } \\
\hline control & $22.0 \pm 4.21$ & $2.54 \pm 0.82$ & $3.03 \pm 0.03$ & $1029.9 \pm 1.03$ & $8.15 \pm 0.21$ \\
\hline 1 experimental & $28.2 \pm 3.85$ & $2.62 \pm 1.09$ & $3.05 \pm 0.04$ & $1029.2 \pm 1.04$ & $8.29 \pm 0.19$ \\
\hline 2 experimental & $25.5 \pm 3.78$ & $2.72 \pm 0.75$ & $3.04 \pm 0.04$ & $1029.1 \pm 1.07$ & $8.24 \pm 0.22$ \\
\hline 3 experimental & $29.7 \pm 4.90$ & $2.93 \pm 0.66$ & $3.08 \pm 0.04$ & $1029.0 \pm 1.07$ & $8.28 \pm 0.20$ \\
\hline \multicolumn{6}{|c|}{ 4th decade (5th control milking) $10 / 14 / 2018$} \\
\hline control & $23.8 \pm 3.25$ & $2.73 \pm 0.98$ & $3.23 \pm 0.04$ & $1030.1 \pm 0.78$ & $8.44 \pm 0.12$ \\
\hline 1 experimental & $28.8 \pm 4.01$ & $2.88 \pm 1.14$ & $3.09 \pm 0.06$ & $1028.9 \pm 0.96$ & $8.29 \pm 0.18$ \\
\hline 2 experimental & $26.2 \pm 3.95$ & $2.77 \pm 1.15$ & $3.12 \pm 0.06$ & $1029.1 \pm 1.10$ & $8.26 \pm 0.22$ \\
\hline 3 experimental & $29.3 \pm 3.60$ & $2.62 \pm 0.93$ & $3.20 \pm 0.05$ & $1029.5 \pm 1.13$ & $8.51 \pm 0.31$ \\
\hline \multicolumn{6}{|c|}{ 5th decade (6th control milking) 10/24/2018 } \\
\hline control & $23.4 \pm 2.92$ & $2.81 \pm 1.13$ & $3.22 \pm 0.08$ & $1030.1 \pm 1.14$ & $8.54 \pm 0.14$ \\
\hline 1 experimental & $23.6 \pm 3.39$ & $2.66 \pm 1.05$ & $3.20 \pm 0.03$ & $1030.1 \pm 1.09$ & $8.51 \pm 0.13$ \\
\hline 2 experimental & $23.0 \pm 2.95$ & $2.56 \pm 0.95$ & $3.16 \pm 0.06$ & $1029.9 \pm 0.93$ & $8.34 \pm 0.17$ \\
\hline 3 experimental & $25.1 \pm 3.26$ & $3.03 \pm 1.10$ & $3.23 \pm 006$ & $1029.8 \pm 1.12$ & $8.45 \pm 0.24$ \\
\hline \multicolumn{6}{|c|}{ 6th decade (7th control milking) 03.11.2018 } \\
\hline control & $22.3 \pm 4.10$ & $3.46 \pm 0.89$ & $3.12 \pm 0.06$ & $1028.8 \pm 1.10$ & $8.34 \pm 0.09$ \\
\hline 1 experimental & $24.1 \pm 3.85$ & $3.68 \pm 0.95$ & $3.10 \pm 0.05$ & $1028.7 \pm 0.93$ & $8.33 \pm 0.13$ \\
\hline 2 experimental & $22.7 \pm 3.92$ & $3.17 \pm 1.01$ & $3.11 \pm 0.06$ & $1029.1 \pm 1.00$ & $8.35 \pm 0.11$ \\
\hline 3 experimental & $25.1 \pm 4.01$ & $3.63 \pm 1.03$ & $3.11 \pm 0.04$ & $1028.9 \pm 1.13$ & $8.33 \pm 0.09$ \\
\hline \multicolumn{6}{|c|}{ 7th decade (8th control milking) $11 / 13 / 2018$} \\
\hline control & $17.6 \pm 3.40$ & $4.11 \pm 0.91$ & $3.05 \pm 0.04$ & $1027,7 \pm 1.12$ & $8.25 \pm 0.09$ \\
\hline 1 experimental & $19.9 \pm 4.11$ & $3.59 \pm 1.03$ & $3.04 \pm 0.06$ & $1027,7 \pm 1.14$ & $8.18 \pm 0.09$ \\
\hline 2 experimental & $21.1 \pm 3.82$ & $3.53 \pm 1.04$ & $3.02 \pm 0.06$ & $1028.7 \pm 1.00$ & $8.16 \pm 0.11$ \\
\hline 3 experimental & $21.6 \pm 3.50$ & $3.92 \pm 0.98$ & $3.02 \pm 0.05$ & $1027.7 \pm 1.05$ & $8.18 \pm 0.10$ \\
\hline \multicolumn{6}{|c|}{ 8th decade (9th control milking) $11 / 23 / 2018$} \\
\hline control & $17.5 \pm 3.44$ & $3.72 \pm 0.91$ & $3.11 \pm 0.04$ & $1028.5 \pm 1.12$ & $8.32 \pm 0.09$ \\
\hline 1 experimental & $21.4 \pm 4.10$ & $3.74 \pm 1.03$ & $3.15 \pm 0.06$ & $1028.8 \pm 1.14$ & $8.36 \pm 0.09$ \\
\hline 2 experimental & $21.9 \pm 3.82$ & $3.61 \pm 1.04$ & $3.06 \pm 0.06$ & $1028.4 \pm 1.00$ & $8.23 \pm 0.11$ \\
\hline 3 experimental & $24.5 \pm 3.50$ & $3.92 \pm 0.98$ & $3.11 \pm 0.05$ & $1028.4 \pm 1.05$ & $8.29 \pm 0.10$ \\
\hline \multicolumn{6}{|c|}{ 9th decade (10th control milking) 03.12.2018 } \\
\hline control & $16.9 \pm 3.38$ & $3.89 \pm 1.01$ & $3.10 \pm 0.03$ & $1028.6 \pm 0.85$ & $8.35 \pm 0.09$ \\
\hline 1 experimental & $20.7 \pm 4.00$ & $3.59 \pm 1.03$ & $3.08 \pm 0.04$ & $1028.3 \pm 0.98$ & $8.27 \pm 0.11$ \\
\hline 2 experimental & $20.0 \pm 3.92$ & $3.45 \pm 0.91$ & $3.06 \pm 0.04$ & $1028.4 \pm 1.00$ & $8.24 \pm 0.10$ \\
\hline 3 experimental & $21.5 \pm 3.65$ & $3.85 \pm 0.89$ & $3.06 \pm 0.05$ & $1028.1 \pm 0.91$ & $8.27 \pm 0.11$ \\
\hline \multicolumn{6}{|c|}{ 10th decade (11th control milking) 13.12.2018 } \\
\hline control & $17.2 \pm 3.92$ & $3.75 \pm 1.00$ & $3.13 \pm 0.04$ & $1028.8 \pm 1.01$ & $8.38 \pm 0.10$ \\
\hline 1 experimental & $21.6 \pm 3.80$ & $3.55 \pm 1.01$ & $3.11 \pm 0.05$ & $1028.6 \pm 1.03$ & $8.31 \pm 0.09$ \\
\hline 2 experimental & $19.4 \pm 4.01$ & $3.61 \pm 0.80$ & $3.06 \pm 0.05$ & $1028.2 \pm 1.00$ & $8.25 \pm 0.09$ \\
\hline 3 experimental & $23.3 \pm 4.00$ & $3.89 \pm 0.95$ & $3.07 \pm 0.03$ & $1028.3 \pm 0.98$ & $8.30 \pm 0.11$ \\
\hline
\end{tabular}


So, the gross milk yield with natural fat content in the groups of cows in the first experimental group was $19584 \mathrm{~kg}$ with a milk fat content of $3.2 \%$, in the second experimental group - $18487 \mathrm{~kg}$ of milk with a fat content of $3.08 \%$, in the third experimental group $20473 \mathrm{~kg}$ of milk with a fat content $3.43 \%$ versus $16928 \mathrm{~kg}$ of milk with a fat content of $3.35 \%$ in the control group.

The gross milk yield of base fat from cows from the third experimental group was 3975 $\mathrm{kg}$ higher than in the control group. In cows from the first experimental group, which were fed with the feed additive Active Mix, the gross milk yield was $2222 \mathrm{~kg}$ lower than in the third experimental group, but $1753 \mathrm{~kg}$ higher than in the control group.

When cows from the second experimental group were fed with both feed additives Active Mix and Ecostimul-2, milk yield was slightly higher than in the control group, but significantly lower than in the first and third experimental groups by 1685 and $3907 \mathrm{~kg}$, respectively.

In terms of the amount of milk fat and protein over the period of the experiment, the best indicators were in the cows from the third experimental group. Cows from this group had $702.2 \mathrm{~kg}$ of milk fat and $634.1 \mathrm{~kg}$ of milk protein versus 567.1 and $523.2 \mathrm{~kg}$ in the control group, respectively.

Table 4. Milk productivity of cows for 100 days of lactation, $\mathrm{M} \pm \mathrm{m}$.

\begin{tabular}{|l|c|c|c|c|}
\hline \multirow{2}{*}{ Index } & \multicolumn{4}{c|}{ Group } \\
\cline { 2 - 5 } & control & I experimental & II experimental & III experimental \\
\hline $\begin{array}{l}\text { Gross milk yield at natural } \\
\text { fat content, kg }\end{array}$ & $16936 \pm 54.8$ & $19584 \pm 45.61 *$ & $18487 \pm 56.73 *$ & $20473 \pm 59.42 *$ \\
\hline $\begin{array}{l}\text { Average fat content of } \\
\text { natural milk, } \%\end{array}$ & $3.35 \pm 0.02$ & $3.20 \pm 0.03$ & $3.08 \pm 0.03$ & $3.43 \pm 0.03 *$ \\
\hline $\begin{array}{l}\text { Average protein content in } \\
\text { milk, \% }\end{array}$ & $3.1 \pm 0.01$ & $3.09 \pm 0.02$ & $3.07 \pm 0.01$ & $3.1 \pm 0.01$ \\
\hline $\begin{array}{l}\text { Gross milk yield at basic } \\
\text { fat content (3.4\%), kg }\end{array}$ & 16679 & 18432 & 16747 & 20654 \\
\hline $\begin{array}{l}\text { The total amount of milk } \\
\text { fat, kg }\end{array}$ & 567.1 & 626.7 & 569.4 & 702.2 \\
- in\% to the control & 100 & 110.5 & 100.4 & 123.8 \\
\hline $\begin{array}{l}\text { The total amount of milk } \\
\text { protein, kg } \\
- \text { in\% to the control }\end{array}$ & 523.2 & 605.5 & 566.8 & 634.1 \\
\hline
\end{tabular}

$$
* \mathrm{P}<0,05
$$

After recalculating for basic fat content, the gross milk yield in the third group was $20654 \mathrm{~kg}$, which is $23.8 \%$ more than in the control group $(16679 \mathrm{~kg})$. Of the remaining groups, the milk yield of cows from the first experimental group approaches the best indicator with a result of $18432 \mathrm{~kg}$ of milk per 100 days of lactation. In cows from the second experimental group for the same period, milk yield was $16747 \mathrm{~kg}$ with a basic fat content, which is slightly higher than the result obtained in the control group.

In the balance experiment, carried out at the end of the scientific and economic experiment, it was found that the cows from the experimental groups digested the nutrients of the feed better than the control ones (Table 5). Thus, the best digestibility of nutrients was observed in cows from the first and third experimental groups. In the second experimental group, the indicators were significantly lower than in the other experimental groups, but higher than in the control group. 
Table 5. Digestibility of dietary nutrients.

\begin{tabular}{|c|c|c|c|c|}
\hline \multirow{2}{*}{ Indicators } & \multicolumn{4}{|c|}{ Group } \\
\cline { 2 - 5 } & control & 1 experimental & 2 experimental & 3 experimental \\
\hline Dry content, $\%$ & $68.4 \pm 0.35$ & $70.5 \pm 0.45$ & $69.1 \pm 0.26$ & $71.3 \pm 0.33^{*}$ \\
\hline Organic content, $\%$ & $66.44 \pm 0.43$ & $68.83 \pm 0.34$ & $68.0 \pm 0.54$ & $71.1 \pm 0.42^{* *}$ \\
\hline Crude protein,\% & $65.63 \pm 0.42$ & $69.72 \pm 0.30^{*}$ & $66.45 \pm 0.45$ & $72.03 \pm 0.40^{* *}$ \\
\hline Crude fat,\% & $61.58 \pm 0.39$ & $64.01 \pm 0.42^{* *}$ & $62.83 \pm 0.38$ & $65.42 \pm 0.42^{* *}$ \\
\hline Crude fiber,\% & $58.47 \pm 0.32$ & $61.42 \pm 0.36^{*}$ & $59.36 \pm 0.40$ & $62.87 \pm 0.38^{* *}$ \\
\hline $\begin{array}{c}\text { Nitrogen-free } \\
\text { extractives, } \%\end{array}$ & $71.73 \pm 1.00$ & $77.46 \pm 0.65^{* * *}$ & $73.44 \pm 0.53^{*}$ & $76.05 \pm 0.54^{* * *}$ \\
\hline
\end{tabular}

$* \mathrm{P}<0,05 ; * * \mathrm{P}<0,01 ; * * * \mathrm{P}<0,001$

From the data in Table 5, it follows that the digestibility of nutrients by groups is different. The coefficient of dry matter digestibility in cows from the 3rd experimental group was the maximum $71.3 \%$ versus $68.4 \%$ in the control group. Organic matter in this group as a whole was digested by $71.1 \%$, crude protein by $72.3 \%$, crude fat by $65.42 \%$, crude fiber by $62.87 \%$ and nitrogen-free extractives by $76.05 \%$. The minimum values for the same indicators were observed in the control group - 66.44\%; 65.63\%; $61.58 \%$; $58.47 \%$; and $71.73 \%$, respectively. The results of the 1 st experimental group were as close as possible to the results of the 3rd group, and the indicators from the 2 nd experimental group were slightly higher than those from the control group. It follows from this that Ecostimul-2 and Active Mix have a positive effect on the digestibility of organic substances, if they are used separately. When they are included in the ration together, the digestibility of organic substances sharply decreases, i.e. it can be assumed that these additives "block" each other, there is an antagonism of their action.

Based on the data of the physiological experiment and the chemical composition of feed, their residues, feces, urine, the nitrogen balance was studied, which can also serve as an indicator of the use of protein in the body of animals, as well as calcium and phosphorus (Table 6).

Table 6. Balance and assimilation of nitrogen.

\begin{tabular}{|c|c|c|c|c|}
\hline \multirow{2}{*}{ Index } & \multicolumn{4}{|c|}{ Group } \\
\hline & control & 1st experimental & 2nd experimental & 3rd experienced \\
\hline Taken with feed, g & $366.5 \pm 2.45$ & $365.2 \pm 3.40$ & $365.8 \pm 2.78$ & $367.3 \pm 3.05$ \\
\hline Excreted in feces, $g$ & $140.3 \pm 2.30$ & $118.6 \pm 2.05$ & $137.4 \pm 2.15$ & $120.8 \pm 2.02$ \\
\hline Digested, $\mathrm{g}$ & $226.2 \pm 2.35$ & $247.2 \pm 2.01 * * *$ & $228.4 \pm 3.12$ & $246.5 \pm 3.04^{* * *}$ \\
\hline Assimilated, $\mathrm{g}$ & $103.9 \pm 1.41$ & $132.0 \pm 1.54 * * *$ & $106.5 \pm 1.56$ & $130.2 \pm 1.30 * * *$ \\
\hline Excreted in urine, $g$ & $122.3 \pm 1.95$ & $115.2 \pm 2.14$ & $121.9 \pm 2.08$ & $116.3 \pm 2.05$ \\
\hline $\begin{array}{l}\text { Excreted with milk, } \\
\mathrm{g}\end{array}$ & $100.7 \pm 1.67$ & $122.5 \pm 1.75^{* * *}$ & $103.0 \pm 1.88$ & $124.1 \pm 2.10 * * *$ \\
\hline $\begin{array}{l}\text { Deposited in the } \\
\text { body, } g\end{array}$ & $3.2 \pm 0.09$ & $9.5 \pm 0.08 * *$ & $3.5 \pm 0.08$ & $6.1 \pm 0.12 *$ \\
\hline \multirow{2}{*}{$\begin{array}{l}\text { Used,\%: } \\
\text { - from the accepted } \\
\text { - from digested }\end{array}$} & 28.35 & 36.09 & 29.11 & 35.45 \\
\hline & 45.93 & 53.4 & 46.63 & 52.82 \\
\hline \multirow{2}{*}{$\begin{array}{l}\text { Used for milk,\%: } \\
\text { - from the accepted } \\
\text { - from digested }\end{array}$} & 27.48 & 33.49 & 28.16 & 33.79 \\
\hline & 44.52 & 49.56 & 45.10 & 5.34 \\
\hline
\end{tabular}

$* \mathrm{P}<0,05 ; * * \mathrm{P}<0,01 ; * * * \mathrm{P}<0,001$

As can be seen from the data in Table 6, cows from the experimental groups used nitrogen better for milk production and lost less with urine. Reliably the best 
indicators were observed in the 1st and 3rd experimental groups. In the second group, the results practically remained at the level of the control group.

In terms of assimilation of calcium and phosphorus, the best indicators were also observed in cows from the first and third groups (Table 7).

Table 7. Balance and utilization of calcium and phosphorus in experimental cows.

\begin{tabular}{|l|c|c|c|c|}
\hline \multirow{2}{*}{\multicolumn{1}{|c|}{ Index }} & \multicolumn{4}{|c|}{ Group } \\
\cline { 2 - 5 } & control & 1st experimental & 2nd experimental & 3rd experienced \\
\hline \multicolumn{5}{|c|}{ Calcium } \\
\hline $\begin{array}{l}\text { Excreted, g: } \\
\text { - with feces }\end{array}$ & $62.2 \pm 1.02$ & $59.1 \pm 1.50$ & $60.9 \pm 1.05$ & $58.1 \pm 1.45$ \\
\hline - with urine & $14.0 \pm 0.15$ & $13.9 \pm 0.13$ & $14.2 \pm 0.20$ & $14.1 \pm 0.18$ \\
\hline - with milk & $30.1 \pm 1.25$ & $33.4 \pm 1.01^{*}$ & $31.2 \pm 1.04$ & $35.2 \pm 0.95^{* *}$ \\
\hline $\begin{array}{l}\text { Deposited in the } \\
\text { body, g }\end{array}$ & $6.10 \pm 0.09$ & $7.9 \pm 0.21$ & $6.40 \pm 0.04$ & $7.4 \pm 0.06$ \\
\hline $\begin{array}{l}\text { Used from } \\
\text { accepted,\% }\end{array}$ & 32.20 & 36.13 & 33.36 & 37.1 \\
\hline incl. for milk & 26.8 & 29.2 & 27.6 & 30.7 \\
\hline & $75.27 \pm 1.22$ & $76.34 \pm 1.04$ & $76.02 \pm 0.92$ & $77.43 \pm 1.07$ \\
\hline Taken with feed, g & $25.9 \pm 0.65$ & $23.1 \pm 0.52$ & $25.8 \pm 0.78$ & $23.5 \pm 0.63$ \\
\hline $\begin{array}{l}\text { Excreted, g: } \\
\text { - with feces }\end{array}$ & $0.98 \pm 0.06$ & $0.99 \pm 0.04$ & $1.05 \pm 0.04$ & $1.01 \pm 0.02$ \\
\hline - with urine & $28.2 \pm 0.81$ & $30.4 \pm 0.75$ & $28.0 \pm 0.72$ & $32.4 \pm 0.68^{*}$ \\
\hline - with milk & 20.19 & 21.85 & 21.17 & 20.52 \\
\hline $\begin{array}{l}\text { Deposited in the } \\
\text { body, g }\end{array}$ & 64.3 & 68.4 & 64.68 & 68.35 \\
\hline $\begin{array}{l}\text { Used from } \\
\text { accepted,\% }\end{array}$ & 37.47 & 39.8 & 36.83 & 41.84 \\
\hline incl. for milk & &
\end{tabular}

$* P<0,05 ; * * P<0,01$

Along with the feed, cows from all experimental groups received approximately the same amount of calcium. The difference between groups is not significant $(\mathrm{P}<0.05)$. Animals from the first experimental group excreted $33.4 \mathrm{~g}$ of calcium with milk, the second group - $31.2 \mathrm{~g}$, and from the third experimental group - $35.2 \mathrm{~g}$ versus $30.1 \mathrm{~g}$ from the control group. The difference with the control group for cows from the 1 st and 3rd experimental groups is significant. In the second experimental group, only $31.2 \mathrm{~g}$ of calcium is excreted with milk. The difference with the control group is insignificant $(\mathrm{P}>$ $0.05)$.

The third group was the best in the assimilation of calcium and phosphorus by cows. The cows used calcium more intensively from the feed intake compared to the control group by $4.9 \%$. These cows used $30.7 \%$ of the calcium taken from the feed for milk production, versus $26.8 \%$ in the control group.

Cows from each group ate approximately the same amount of feed, respectively received the same amount of phosphorus (from $75.27 \mathrm{~g}$ to $77.43 \mathrm{~g}$ ). Cows from the 3rd experimental group excreted more phosphorus with milk than cows from other groups. So, in the $3 \mathrm{rd}$ experimental group this indicator was $32.4 \%$ versus $28.2 \%$ in the control group. Accordingly, from all groups, cows from the 3rd experimental group used phosphorus for milk $41.84 \%$ of the amount taken with feed. In the control group, this Fig. was only $37.47 \%$. 
Based on the indices of the digestibility of nutrients, the balance and assimilation of nitrogen, calcium and phosphorus, it has been established that feed additives Active Mix and Ecostimul-2 have a positive effect on metabolism, they activate the action of the digestive system. As a result, the coefficients of digestibility of organic substances in the 1 st and 3rd experimental groups are higher than in the control group. A similar picture is observed in the balance and absorption of calcium and phosphorus. Along with this, it was found that with the simultaneous inclusion of the optimal amount of Active Mix and Ecostimul-2 in the ration of cows from the 2nd experimental group, the digestibility of the studied nutrients, as well as the absorption coefficients of calcium and phosphorus, decreased. This means that with the simultaneous use of these feed additives, antagonism of their action occurs, i.e. they neutralize each other's actions.

In order to get a calf from a cow every year, it is necessary to control the duration of the service period. After calving, cows should be fruitfully inseminated within $80-85$ days (Table 8).

Table 8. Results of insemination of experimental cows.

\begin{tabular}{|l|c|c|c|}
\hline \multirow{2}{*}{ Group } & \multicolumn{3}{|c|}{ Condition of cows } \\
\cline { 2 - 4 } & not inseminated & inseminated & fertilized \\
\hline Control & 3 & 5 & 1 \\
\hline 1st experimental & 1 & 7 & 4 \\
\hline 2nd experimental & 2 & 6 & 4 \\
\hline 3rd experienced & - & 8 & 2 \\
\hline
\end{tabular}

Analysis of the results of insemination of cows shows that on the 85 th day 3 cows remained not inseminated. In the first and second experimental groups, respectively, one and two cows were not inseminated. In the third experimental group, there were no noninseminated cows. The reason for the lack of estruation, in our opinion, was poor recovery after calving and a sharp decrease in live weight. When checked, 5 cows from the control group came to estruation at least once, one of them with a confirmed pregnancy. In the first experimental group 7 cows were inseminated, one of them - again, and 4 with a confirmed pregnancy. In the second experimental group 6 cows were inseminated, one head had to be inseminated again. At the time of the check, two cows were fertilized. In the third experimental group all cows ( 8 heads) were inseminated, one of them was re-inseminated. Confirmed pregnancy was recorded in 4 cows. From the data in Table 9, it can be seen that the reproductive functions of cows that receive $300 \mathrm{~g}$ of Active Mix (first group) are better than those of cows from the control and second experimental groups. The most massive and timely onset of estruation was observed in cows from the 3rd experimental group, where $300 \mathrm{mg}$ of Ecostimul-2 was used as a feed additive. Thus, it can be concluded that the used feed additives had a positive effect on the reproductive qualities of cows.

The quantitative indicators obtained in experimental studies do not fully prove the justification of the costs of purchasing additives and their return on investment. To substantiate the effectiveness of the use of the proposed feed additives in the rations of freshly calved cows, based on the results of scientific and economic experience, changes in such economic indicators as the cost of milk, profit and profitability were calculated and analyzed (Table 9).

When recalculated for basic fat content, it was found that among the experimental groups, the lowest costs for milk production were in the third experimental group. 
Table 9. Economic efficiency of milk production for the period of scientific and economic experience.

\begin{tabular}{|l|c|c|c|c|}
\hline \multicolumn{1}{|c|}{ Index } & Control & 1 experienced & 2 experienced & 3 experienced \\
\hline Number of heads & 8 & 8 & 8 & 8 \\
\hline $\begin{array}{l}\text { Duration of the experiment, } \\
\text { days }\end{array}$ & 100 & 100 & 100 & 100 \\
\hline $\begin{array}{l}\text { Milk obtained with natural fat } \\
\text { content, kg }\end{array}$ & 16936 & 19584 & 18487 & 20473 \\
\hline $\begin{array}{l}\text { Relative to the control } \\
\text { group,\% }\end{array}$ & 100 & 115.6 & 109.2 & 120.9 \\
\hline $\begin{array}{l}\text { Received milk with basic fat } \\
\text { content, kg }\end{array}$ & 16679 & 18432 & 16747 & 20654 \\
\hline $\begin{array}{l}\text { Relative to the control } \\
\text { group,\% }\end{array}$ & 100 & 110.5 & 100.4 & 123.8 \\
\hline $\begin{array}{l}\text { Average daily milk yield per } \\
\text { cow, kg }\end{array}$ & 21.17 & 24.48 & 23.1 & 25.6 \\
\hline $\begin{array}{l}\text { Costs per group of cows, } \\
\text { rubles }\end{array}$ & 406539 & 439419 & 442659 & 409779 \\
\hline Additional costs, rub. & - & 32880 & 36120 & 3240 \\
\hline $\begin{array}{l}\text { Selling price of 1 kg of milk, } \\
\text { rubles }\end{array}$ & 28.0 & 28.0 & 28.0 & 28.0 \\
\hline $\begin{array}{l}\text { Revenue from the sale of } \\
\text { milk, rubles }\end{array}$ & 467012 & 516096 & 468916 & 578312 \\
\hline In \% to the control group & 100 & 110.5 & 100.4 & 123.8 \\
\hline $\begin{array}{l}\text { Selling price of 1 kg of milk, } \\
\text { rubles }\end{array}$ & 28.0 & 28.0 & 28.0 & 28.0 \\
\hline $\begin{array}{l}\text { Prime cost of 1 kg of milk } \\
\text { with basic fat content, rubles }\end{array}$ & 24.37 & 23.84 & 26.45 & 19.84 \\
\hline In \% to the control group & 100 & 97.8 & 108.5 & 81.41 \\
\hline Gross profit, RUB & 604.73 & 76677 & 26257 & 168533 \\
\hline Profit per head, rub. & 7559 & 9585 & 3282 & 21067 \\
\hline Profitability level,\% & 14.9 & 17.4 & 5.9 & 41.1 \\
\hline
\end{tabular}

So, due to the increase in milk production, the gross profit in the first experimental group in relation to the control group is $26.8 \%$ higher, which in total amounted to 2,026 rubles from each head of additional profit. In the third experimental group, the gross profit was obtained 2.78 times more in relation to the control group, which amounted to 13508 rubles additionally from each head. In the second test group, the gross profit indicators decreased.

\section{Discussion}

During the period of scientific and economic experience, it was established that for 100 days of lactation, the loss of live weight associated with milk production in the control group was $37 \mathrm{~kg}$, in the 1 st experimental group - $35 \mathrm{~kg}$, in the $2 \mathrm{nd}$ experimental group 49 $\mathrm{kg}$ and in the $3 \mathrm{rd}$ th $-29 \mathrm{~kg}$. The relative loss of live weight for the same groups was: $6.5 \%,-6.3 \%,-8.6 \%$ and $-5.3 \%$, respectively.

Used additives had a positive effect on the milk production of cows. The gross milk yield in the 1st experimental group was $19584 \mathrm{~kg}$, in the 2 nd experimental group - 18487 $\mathrm{kg}$ and in the $3 \mathrm{rd}$ experimental $-20473 \mathrm{~kg}$, versus $16936 \mathrm{~kg}$ in the control group. The average fat content of natural milk was respectively $3.2 \%, 3.08 \%$ and $3.43 \%$ versus $3.35 \%$ in the control group. The results are similar for the total amount of milk fat and protein 
obtained. The 3rd test group remains the Best Group, with 23.8\% more milk fat and 21.2\% more milk protein than the control group.

The best digestibility of nutrients was observed in the first and third test groups. The digestibility of dry matter in the $3 \mathrm{rd}$ experimental group was the maximum $71.3 \%$ versus $68.4 \%$ in the control group. Organic substances in the 3rd experimental group were digested by $71.1 \%$, crude protein $-72.3 \%$, crude fat $-65.42 \%$, crude fiber $-62.87 \%$, nitrogen-free extractive substances - 76.05\%. The minimum values for the studied parameters were observed in the control group. The results on the milk productivity of cows from the 1st experimental group are as close as possible to the results of the 3rd group. The productive indicators of cows from the 2 nd experimental group were slightly higher than in the control. This pattern persisted in the balance and use of nitrogen, calcium and phosphorus. The morphobiochemical blood parameters remained within the physiological norm.

Reproductive qualities of fresh cows on the 85th day showed that the most massive and timely onset of estruation was observed in cows from the 3rd experimental group. All 8 cows were inseminated, 4 of them with confirmed pregnancy. In the control group, by this time, 3 cows were not inseminated, and only one cow was with a confirmed pregnancy. Analysis of the results of scientific and economic experience showed that in terms of economic efficiency, the best group was the 3rd experimental group, which received 300 $\mathrm{mg}$ of Ecostimul-2 per head per day. The level of profitability of milk production in this group was $41.1 \%$ versus $14.9 \%$ in the control group, while in the 1 st experimental group the profitability was $17.4 \%$, and in the 2 nd experimental group $-5.9 \%$.

Based on the results of the scientific and economic experience, it can be concluded that the best results were obtained in the 3rd experimental group when feeding the cows with Ecostimul-2 additives in the amount of $300 \mathrm{mg}$. It is also justified to use $300 \mathrm{~g}$ of Active Mix as a feed additive. And the joint inclusion of these additives does not give the desired result and is not justified in terms of zootechnics and production economics.

\section{Conclusion}

Based on the results of scientific and economic experience, the following conclusions can be drawn:

1. In a comparative study of the feeding of feed additives Ecostimul-2 (300 mg per head per day) and Active Mix (300 g per head per day), it was found that the best indicators of milk productivity of cows and their reproductive functions were in cows when included monofeed Ecostimul-2 in the composition.

2. With the simultaneous inclusion of Ecostimul-2 and Active Mix in the composition of monofeed, cows from the second experimental group are observed to have antagonism of their action. The milk productivity of cows from this group was lower compared to the first and third experimental groups and slightly exceeded the productivity of cows from the control group.

\section{Reference}

1. S. V. Alekseev, G. E. Uskov Protein and mineral supplements in the rations of cattle: recommendations Kurgan: KGSHA, 50 (2011)

2. O. A. Artemyeva, D. A. Pereselkova, Yu. P. Fomichev Biologically active drug as an alternative to the use of antibiotics against pathogenic microorganisms, Agricultural Biology, 50 4, 513-519 (2015) 
3. A.V. Arkhipov Antioxidants in animal husbandry Actual problems of biology in animal husbandry, Proceedings of the V int. Conf 129-140 (2010)

4. N. Lushnikov, P. Podgorbunskikh, N. Kostomakhin The state of the industry and modern trends in the development of animal husbandry, Chief livestock technician. - , 5, 7 - 18 (2016)

5. L. Romanenko, V. Volgin, Z. Fedorova Control of the nutritional value of highly productive cows, Dairy and beef cattle breeding, 3, 14-15. (2010)

6. D.A. Yurin, N.A. Yurina, N.N. Esaulenko Effective approaches to feeding highly productive cows Effective animal husbandry, 2, 16-18. (2017)

7. A. P. Bulatov, S. F. Sukhanova, A. A. Kurdoglian Razdoy cows on pasture grass and premixes Feeding of farm animals and forage production, 9, 11-17. (2009)

8. G.V. Davydenkov Complex use of choline, L-carnitine and dihydroquercetin in the prevention of ketosis in highly productive dairy cows (2011)

9. E. V. Dushkin Dependence of milk productivity on the state of the liver after calving Veterinary of agricultural animals, 2, 35-39(2010)

10. Yu. P. Fomichev Natural feed additives Ecostimul and Arabinogalactan in ecology, productive use of animals and poultry and feed industry. Practical instruction. (2010)

11. A. Denkin Influence of the concentration of energy in the diets of dry cows on milk productivity and dynamics of live weight Feeding farm animals and fodder production. , 4. 17-21 (2008)

12. M. P. Kirillov Energy feed additive in the diet of highly productive cows Chief zootechnik, 1, 5-8 p. (2006)

13. L.V. Smirnova, A.I. Suslova, S.V. Popova Influence of carbohydrate concentrate "MinvitR dry syrup" on productivity and quality of milk in cows Agriculture of Russia. Science and Practice (Price Digest), 24-26. (2013)

14. R. L. Sharvadze The inclusion of propylene glycol in the diets when milking cows Ecological and biological welfare of the plant and animal world, 157 (2017) 